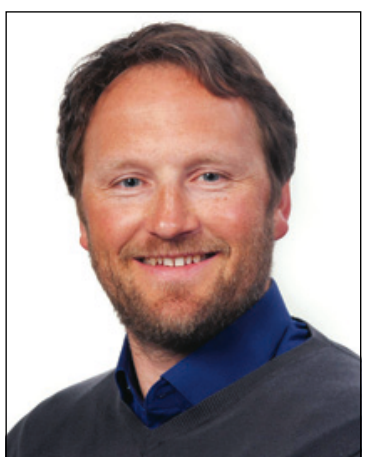

Bjørn Heine Strand er en av fem medforfattere. Foto: Bjørn Kåre Iversen

\section{Kom deg opp av stolen!}

\author{
Middelaldrende personer med høy fysisk funksjonsevne lever lenger \\ enn dem med lav fysisk funksjonsevne.
}

En nylig publisert undersøkelse (1) brukte data fra den britiske 1946-kohorten, som er en av de lengste livsløpsstudiene $\mathrm{i}$ aldring. I underkant av 3000 individer født samme uken i mars 1946 i England, Skottland og Wales ble fulgt opp for å se om tre enkle objektive tester av fysisk funksjonsevne var assosiert med høyere overlevelse. I løpet av en 13 års oppfølgingsperiode døde i underkant av 200 personer som var inkludert.

Tre tester ble målt ved 53-årsalderen. Disse innebar gripestyrke, å reise seg fra stol ti ganger og måling av balanse. Personene ble sortert i fem grupper for hvert av målene etter hvor god funksjon de hadde. De som ikke klarte å gjennomføre noen av testene ble plassert $\mathrm{i}$ egen gruppe. Funnene viser en klar sammenheng mellom alle tre funksjonsmålene og dødelighet. De som ikke gjennomførte noen av testene hadde 12 ganger høyere dødelighetsrate enn dem som gjennomførte alle.

- Vi tok hensyn til flere faktorer som henger sammen med både funksjonsevne og dødelighet, slik som kroppsvekt, livsstilsfaktorer som fysisk aktivitet og røyking, sosioøkonomisk posisjon samt helsetilstand inkludert kreft, hjertesykdom, diabetes, lungesykdom eller symptomer på dette, sier seniorforsker Bjørn Heine Strand ved Folkehelseinstituttet og artikkelens andreforfatter.

- I tidligere undersøkelser har man funnet sammenheng mellom fysisk funksjonsevne og levealder, men disse studiene har vært gjort på eldre mennesker. Dette er den første studien som ser på middelaldrende personer, der god fysisk funk- sjonsevne kan reflektere både diagnostisert sykdom, men også uoppdaget sykdom i en tidlig fase og aldringsprosesser. Fysisk funksjonsevne kan også gjenspeile et livsløp med eksponering for risikofaktorer som er assosiert med tidlig død, slik som inaktivitet, og røyking, sier Strand.

- Resultatene tyder på at forebygging må starte tidlig i livet og at man må studere hele livsløpet når man studerer aldring. Det trengs imidlertid mer forskning på hva slags tiltak som er de beste for å bedre funksjonsevnen for denne gruppen, mener Strand.

\section{Forskergruppen}

Studien springer ut ifra et toårig postdoktorstipend i livsløpsepidemiologi, som seniorforsker Bjørn Heine Strand fikk fra National Institute on Aging (NIA) og National Institutes of Health (NIH) i USA i perioden 2008-10. Stipendet var et samarbeid mellom University College London, University of Washington og Folkehelseinstituttet, tilknyttet analyse av Den britiske 1946-kohorten i London. I sluttfasen av dette postdoktoroppholdet ble artikkelen påbegynt og alle medforfatterne bidro i felleskap til idé, design og utforming av studien. Cooper og Strand gjorde i fellesskap de statistiske analysene.

\section{Tor Atle Rosness \\ Tidsskriftet}

\section{Litteratur}

1. Cooper R, Strand BH, Hardy R et al. Physical capability in mid-life and survival over 13 years of follow-up: British birth cohort study. BMJ 2014: 348: g2219.
Ordforklaringer:

Kohort: En avgrenset gruppe mennesker.

Dynamometer: Redskap til å måle gripestyrke. Cox-regresjon: Statistisk metode for å analysere forløpsdata.

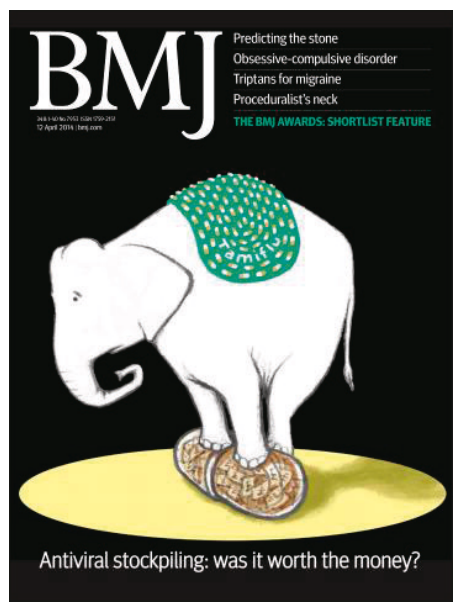

Artikkelen er publisert i $B M J$, som er et av de fem høyest rangerte medisinske tidsskriftene i verden, i april 2014 